\title{
Roberto Melaragno's scientific contributions to Brazilian Neurology
}

\author{
As contribuições científicas de Roberto Melaragno à Neurologia Brasileira \\ João Carlos Papaterra LIMONGI', Plinio Marcos Garcia LIMA², Sonia Maria César de Azevedo SILVA, \\ Matheus Gomes FERREIRA², Egberto Reis BARBOSA¹, Hélio Afonso Ghizoni TEIVE ${ }^{2}$
}

\begin{abstract}
Roberto Melaragno Filho, an associate professor of neurology at the School of Medicine of Universidade de São Paulo and head of the neurology service at Hospital do Servidor Público Estadual Francisco Morato Oliveira (HSPE-FMO), had a significant scientific career. He is recognized as a reference in the $20^{\text {th }}$ century Brazilian neurology in addition to having a notable international career.
\end{abstract}

Keywords: Neurology; History; Stroke; Multiple Sclerosis; Parkinsonian Disorders.

\section{RESUMO}

Roberto Melaragno Filho, professor livre-docente em neurologia pela Faculdade de Medicina da Universidade de São Paulo, e chefe do serviço de neurologia do Hospital do Servidor Público Estadual Francisco Morato de Oliveira (HSPE-FMO), teve uma carreira científica de grande relevo, sendo reconhecido nacionalmente como uma das referências em neurologia no século XX, além de ter tido uma notável carreira internacional.

Palavras-chave: Neurologia; História; Acidente Vascular Cerebral; Esclerose Múltipla; Transtornos Parkinsonianos.

\section{INTRODUCTION}

Brazilian neurology, particularly in São Paulo, was strongly influenced by French neurology ${ }^{1,2}$. The first chair of neurology at the School of Medicine of Universidade de São Paulo (USP) was filled by professor Enjolras Vamprè in 1935; after his premature death in 1938, his assistant professor Aderbal Tolosa was chosen to replace him through an open selection process ${ }^{2,3,4,5}$. In 1945 , the neurology clinic at the School of Medicine of USP was transferred to Hospital das Clínicas under the leadership of Tolosa and his assistants Oswaldo Lange and Oswaldo Freitas Julião, along with several volunteer assistants, including Roberto Melaragno Filho ${ }^{3,4,5,6,7,8}$. Melaragno had exceptional didactic capacity and relevant scientific production, and came to represent Brazilian neurology to the rest of the world ${ }^{7}$. This historical review presents Roberto Melaragno's main contributions to Brazilian neurology.

\section{ROBERTO MELARAGNO FILHO — BIOGRAPHY}

Roberto Melaragno Filho (Figure 1) was born in São Paulo in 1919 and obtained his degree in medicine from the School of Medicine of USP in 1942,8. In 1943, he began working as a volunteer assistant at the neurology clinic of USP, Hospital das Clinicas, under the supervision of Aderbal Tolosa ${ }^{3,4,7,8}$. In 1947 and 1948, he completed his studies as an Assistant Foreigner at the School of Medicine of Paris under professor Raymond Garcin ${ }^{7.8}$. Melaragno was appointed Free Lecturer at USP in 1954 and remained very active in the neurology service through didactic and scientific work until leaving in 1965 to take over as the head of the neurology service at Hospital do Servidor Público Estadual Francisco Morato de Oliveira (HSPE-FMO) 34,6,7,8. There, he was responsible for training many neurologists until his retirement in $1989^{7,8}$. Melaragno was a founding member of the Brazilian Academy of Neurology; he was a frequent participant in congresses

\footnotetext{
${ }^{1}$ Universidade de São Paulo, Departamento de Neurologia, Hospital das Clínicas, São Paulo SP, Brazil.

${ }^{2}$ Universidade Federal do Paraná, Departamento de Clínica Médica, Serviço de Neurologia, Hospital de Clínicas, Curitiba PR, Brazil.

${ }^{3}$ Universidade Federal de São Paulo, Escola Paulista de Medicina, Departamento de Neurologia, São Paulo SP, Brazil.

João Carlos Papaterra LIMONGI (D) https://orcid.org/0000-0003-1684-0154; Plinio Marcos Garcia LIMA (D) https://orcid.org/0000-0001-6143-6666;

Sonia Maria César de Azevedo SILVA (iD) https://orcid.org/0000-0002-9937-2175; Matheus Gomes FERREIRA (iD https://orcid.org/0000-0002-5288-4739;

Egberto Reis BARBOSA (D) https://orcid.org/0000-0002-6996-9130; Hélio Afonso Ghizoni TEIVE (D) https:/orcid.org/0000-0003-2305-1073

Correspondence: Hélio Teive; E-mail: hagteive@mps.com.br

Conflict of interest: There is no conflict of interest to declare.

Authors' contribution: The authors declare that they have each made important contributions to the acquisition, analysis, and interpretation of the data.

Received on June, 22, 2020; Accepted on July 26, 2020.
} 
and sponsored the creation of the Henrique Sam Midlin award. In 1998, on the eve of his seventy-ninth birthday, he died in the city of São Paulo ${ }^{7,8}$.

Professor Melaragno together with Professor Luiz Augusto Franco de Andrande, from Escola Paulista de Medicina (Universidade Federal de São Paulo) were the creators and first coordinators of the Brazilian Academy of Neurology working group on extrapyramidal diseases, today, movement disorders scientific department. On March $11^{\text {th }}, 1985$, in the city of São Paulo/SP, the group was created with the presence of several neurologists and with the participation of an international guest, Professor Urpo Rinne from Filand. In the following year, Professor Melaragno and Professor Franco de Andrade organized an international symposium on movement disorders, that took place in the cities of Rio de Janeiro and São Paulo, with the participation of Professor C.D. Marsden (from the United Kingdom) and Professor Yves Agid (from France). Today the Associação Paulista de Medicina awards Professor Roberto Melaragno Filho.

\section{RELEVANT SCIENTIFIC CONTRIBUTIONS TO NEUROLOGY}

Melaragno published several scientific articles in Brazil, mainly in Arquivos de Neuro-Psiquiatria (the official journal

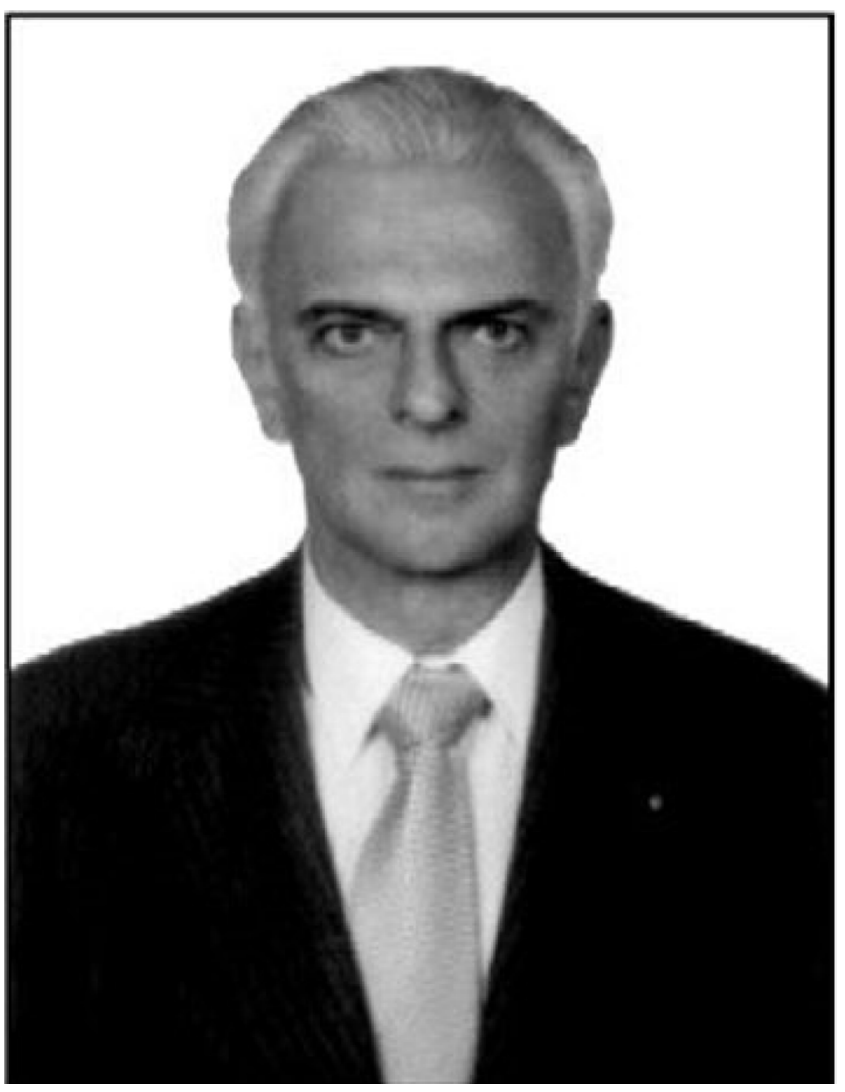

Source: Paiva Melo?

Figure 1. Roberto Melaragno Filho (1919-1998). of the Brazilian Academy of Neurology), and abroad, particularly in France $e^{9,10,11,12,13,14,15}$. Initially, he published on general neurology, then made more frequent contributions in the areas of cerebrovascular diseases and, later, neuroimmunology and multiple sclerosis, including books on these topics ${ }^{7,8,15}$. Notable articles addressed cerebrovascular diseases, studies on the pharmacology of cerebral circulation, thrombosis of the internal carotid artery, intracranial aneurysms, and clinical hemorheology in the study of cerebral blood flow ${ }^{12,14}$. In neuroimmunology he published articles on cerebrospinal fluid immunoglobulins $\mathrm{G}$ in nervous system diseases ${ }^{15}$, and on the topic of neuromuscular diseases, he addressed ocular myopathy, periodic paralysis, and Charcot-Marie disease ${ }^{10}$. In the area of movement disorders, he published articles on cerebellar ataxias, with one of the first descriptions of Pierre-Marie heredo-ataxia or spinocerebellar degeneration (today known as spinocerebellar ataxia or SCAS) in Brazil ${ }^{9}$ (Figure 2). He also published case reports about myoclonic cerebellar dyssynergy, Hallervorden-Spatz syndrome, Parkinsonian disorders and dementia, and Parkinson disease, and was a pioneer in the use of levodopa in Brazil ${ }^{11,13,16}$. He was also the author of several case reports in general neurology, particularly in the

\section{CONSIDERAÇOES SOBRE AS HEREDO-DEGENERAÇOES ESPINHO-CEREBELARES}

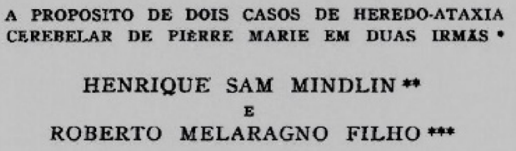

Entre as afecçóes hereditarias e familiares do sistema nervoso destacam-se, por sua maior freqüencia e importância, a moléstia de Friedreich (1861), a heredo-ataxia cerebelar de Pièrre Marie (1893) e a paraplegia espástica de Strümpell (1893).

O problema dessas afecçóes familiares apresenta certos aspéctos interessantes que, ainda hoje, constituem campo aberto à discussão entre os neuropatologistas. Antes de relatar os casos clínicos por nós observados, estudaremos as questóes ligadas à etiopatogenia $\mathrm{e}$ ao conceito, unicista ou pluralista, das heredo-degenerações espinho-cerebelares. Dispensamos a descrição dos quadros sintomatólogicos dessas moléstias, pois que os mesmos são sobejamente conhecidos.

Constituem essas afecçōes diferentes entidades nosológicas ou representam apenas formas diversas de um mesmo grupo de moléstias hereditarias do sistema nervoso e dependentes tão somente da variabilidade na localizaçăo das lesöes? Divergências existem ainda a esse respeito, dividindo-se os autores entre os que aceitam o conceito unicista e os que continuam a considerar cada uma das afecçóes indicadas como individualidade nosológica autonoma.

Ayala (1) e Strümpell (2) em seus tratados, seguem a opinião de Bing o qual considera a heredo-ataxia cerebelar como uma sub-especie frequente e relativamente caracteristica da moléstia de Friedreich. Do mesmo modo, Walshe (3) considera em conjunto as heredo-ataxias, Draba apresenta a seceno

* Trabalho apresentado à Secção de Neuropsiquiatria da Associação Paulista de Medicina, em 5 de Dezembro de 1942, acompanhado de filme
cinematográfico. cinematográfico.

sidade de S. Paulo.

*** Assistente voluntario do Serviço de Neurologia da Universidade de

Paulo. Ayala, G. - Medicina Interna Vol. V, 2. ed. - Turim, 1936

(1) Ayala, G. - Medicina Interna. Vol. V, 2.* ed. Turim, 1936.

e Terapia. Vol. II, Parte II. Trad. Ital. 1936.

(3) Walshe, F. M. R. - Diseases of the Nervous System. 1940.

Source: reproduced from reference 9

Figure 2. Sam Mindlin \& Melaragno's paper about spinocerebellar ataxias published in 1943. 
Brazilian journal Arquivos de Neuro-Psiquiatria ${ }^{7,8}$. One of his most significant studies discussed gait disorders in patients with parkinsonian disorders, presenting different subtypes of freezing ${ }^{17}$.

\section{INTERNSHIP IN PARIS WITH RAYMOND GARCIN}

During the two years he interned at the School of Medicine of Paris under Raymond Garcin, Melaragno published important studies that allowed him to obtain the title of Foreign Assistant ${ }^{7,8}$. He studied motor phenomena that can occur in movement disorders syndromes, particularly parkinsonian disorders, assessing the "kinetic restraint" ("enrayage cinétique") of the gait, characterized by the presence of a gait disorder, or the occurrence of quick steps in the same place during movement ("signe de piétinement," "trampling sign"). Another gait disorder he studied was defined as "bégaiement de la mise en route," currently considered a gait block or freezing, which tends to occur in parkinsonian patients. Another topic discussed in the same article was perseverance or tonic innervation, in which patients exhibit a sudden inhibition during voluntary movements, with their limbs frozen for seconds in bizarre positions. In Melaragno's time, this phenomenon was considered an extreme manifestation of bradykinesia and was related to motor blocks or freezing, as it is currently defined ${ }^{17}$.

Professor Roberto Melaragno Filho is recognized as one of Brazil's most important professors of neurology and made major contributions to solidify neurology as a specialty in the state of São Paulo and across the country ${ }^{7,8}$. His scientific publications in Brazil and abroad were relevant in several different areas of neurology, combined with his presence in domestic and international professional congresses, led the late Dr. Antonio Spina-França to describe him as an world ambassador for Brazilian neurology ${ }^{7}$.

\section{References}

1. Leite Neto AM. A influência da escola neurológica francesa na fundação da neurologia brasileira. In: Reimão R. História da Neurologia no Brasil. São Paulo: Lemos Editorial; 1999. p. 25-34.

2. Meira AT, Betini BG, Cardoso F, Gomes MM, Barbosa ER, Prado RC, et al. First stages towards the establishment of Brazilian neurology faculties. Arq Neuro-Psiquiatr. 2019 Dec;77(12):888-95. https://doi. org/10.1590/0004-282X20190147

3. Pinto Pupo P. Contribuição para a história da neurologia em São Paulo. Arq Neuro-Psiquiatr 1963 Mar;21(1):44-50. http://dx.doi. org/10.1590/S0004-282X1963000100008

4. Assis JL. A escola neurológica de São Paulo. In: Reimão R. História da Neurologia no Brasil. São Paulo: Lemos Editorial; 1999. p. 205-11.

5. Tolosa A. Clínica Neurológica da Faculdade de Medicina da Universidade de São Paulo. Arq Neuro-Psiquiatr 1944 Apr-Jun;2(2):203-10. https://doi.org/10.1590/S0004$282 \times 1944000200007$

6. Hospital das Clínicas FMUSP. Neurologia. Histórico. São Paulo. Available from: https://www.fm.usp.br/neurologia/departamento/ historico

7. Paiva Melo AC. In Memoriam. Roberto Melaragno Filho. Arq NeuroPsiquiatr 1998 Jun;56(2):328. https://doi.org/10.1590/S0004282X1998000200032

8. Spina-França A. In memoriam. Roberto Melaragno Filho. Arq Neuro-Psiquiatr 1998 Jun;56(2):329. https://doi.org/10.1590/S0004$282 \times 1998000200032$

9. Mindlin HS, Melaragno Filho R. Considerações sobre as heredodegenerações espinho-cerebelares. A propósito de dois casos de heredo-ataxia cerebelar de Pierre-Marie em duas irmãs. Arq NeuroPsiquiatr. 1943 Jan-Jun;1(1):26-42. http://dx.doi.org/10.1590/S0004282X1943000100004
10. Julião OF, Melaragno Filho R. Distrofia muscular familial. A propósito de três casos de moléstia de Steinert. Arq NeuroPsiquiatr. 1943 Sep;1(2):101-18. http://dx.doi.org/10.1590/S0004$282 \times 1943000200002$

11. Pernambuco J, Melaragno Filho R. Dissinergia cerebelar muiclônica; a propósito de um caso. Arq Neuro-Psiquiatr. 1945 Oct;27:317.

12. Melaragno Filho R. Pharmacology of cerebral circulation; experimental contribution. Arq Neuro-Psiquiatr. 1954;12(2):1-126.

13. Melaragno Filho R, Karam GM. Treatment of parkinsonism with L-dopa. Arq Neuro-Psiquiatr. 1971;29(4):419-27.

14. Melaragno Filho R. The importance of clinical hemorheology inthe study of cerebral blood flow in normal conditions and in cerebrovascular ischemia. Arq Neuro-Psiquiatr. 1995 Mar;53(1):15768. https://doi.org/10.1590/s0004-282×1995000100025

15. Livramento JA, Melaragno Filho R, Spina-França A. Cerebrospinal fluid $\mathrm{G}$ immunoglobulins in nervous system diseases. Arq NeuroPsiquiatr. 1981 Jun;39(2):156-61. https://doi.org/10.1590/s0004$282 \times 1981000200004$

16. Bresolin AU, Pascuzzi L, Melaragno Filho R, Fontana MH, Pecorta R, Souza Dias JC. "Hallervorden-Spatz syndrome- infantile neuroaxonal dystrophy complex". Case report. Arq Neuro-Psiquiatr. 1988 Mar:46(1):69-72.

17. Melaragno Filho R. Sur quelques aspects des troubles de la dènervation volontaire - enrayage cinétique, perseveration tonicque, "Begaiement de la mise em route du mouvement", piétinement - observes dans les syndromes extrapyramidaux et sur leur relation avec quelques autres phénomenes analogues observes em neuropathologie. Arq Neuro-Psiquiar. 1948 Oct-Dec;6(4):334-51. https://doi.org/10.1590/S0004$282 \times 1948000400002$ 